\title{
Correction to: Parkinson's disease-related Leucine-rich repeat kinase 2 modulates nuclear morphology and genomic stability in striatal projection neurons during aging
}

Xi Chen ${ }^{1,2}$, Chengsong Xie ${ }^{1}$, Wotu Tian ${ }^{1,3}$, Lixin Sun ${ }^{1}$, Wang Zheng ${ }^{1}$, Sarah Hawes ${ }^{1}$, Lisa Chang ${ }^{1}$, Justin Kung ${ }^{1}$, Jinhui Ding ${ }^{4}$, Shengdi Chen ${ }^{3}$, Weidong Le $^{2}$ and Huaibin Cai ${ }^{1^{*}}$

\section{Correction to: Mol Neurodegeneration https://doi.org/10.1186/s13024-020-00360-0}

The original article [1] had mistakenly inverted co-author, Wang Zheng's name. This has since been corrected.

\section{Author details}

${ }^{1}$ Transgenic Section, Laboratory of Neurogenetics, National Institute on Aging, National Institutes of Health, Building 35, Room 1A112, MSC 3707, 35 Convent Drive, Bethesda, MD 20892-3707, USA. ${ }^{2}$ Clinical Research Center on Neurological Diseases, the First Affiliated Hospital, Dalian Medical University, Dalian 116011, People's Republic of China. ${ }^{3}$ Department of Neurology, Ruijin Hospital Affiliated to Shanghai Jiao Tong University School of Medicine, Shanghai 20025, China. ${ }^{4}$ Computational Biology Group, Laboratory of Neurogenetics, National Institute on Aging, National Institutes of Health, Bethesda, MD 20892, USA.

Published online: 16 March 2020

\section{Reference}

1. Chen $X$, et al. Parkinson's disease-related Leucine-rich repeat kinase 2 modulates nuclear morphology and genomic stability in striatal projection neurons during aging. Mol Neurodegeneration. 2020;15:12 https://doi.org/ 10.1186/s13024-020-00360-0.

The original article can be found online at https://doi.org/10.1186/s13024 020-00360-0

* Correspondence: caih@mail.nih.gov

${ }^{1}$ Transgenic Section, Laboratory of Neurogenetics, National Institute on Aging, National Institutes of Health, Building 35, Room 1A112, MSC 3707, 35 Convent Drive, Bethesda, MD 20892-3707, USA

Full list of author information is available at the end of the article

(c) The Author(s). 2020 Open Access This article is licensed under a Creative Commons Attribution 4.0 International License, which permits use, sharing, adaptation, distribution and reproduction in any medium or format, as long as you give appropriate credit to the original author(s) and the source, provide a link to the Creative Commons licence, and indicate if changes were made. The images or other third party material in this article are included in the article's Creative Commons licence, unless indicated otherwise in a credit line to the material. If material is not included in the article's Creative Commons licence and your intended use is not permitted by statutory regulation or exceeds the permitted use, you will need to obtain permission directly from the copyright holder. To view a copy of this licence, visit http://creativecommons.org/licenses/by/4.0/ The Creative Commons Public Domain Dedication waiver (http://creativecommons.org/publicdomain/zero/1.0/) applies to the data made available in this article, unless otherwise stated in a credit line to the data. 